\begin{tabular}{|l|l|l||}
\hline \multicolumn{2}{|c|}{ PublisherInfo } \\
\hline \hline PublisherName & $:$ & BioMed Central \\
\hline \hline PublisherLocation & $:$ & London \\
\hline \hline PublisherImprintName & $:$ & BioMed Central \\
\hline \hline
\end{tabular}

\title{
2D gels are not enough
}

\begin{tabular}{|l|l|l||}
\hline \multicolumn{2}{|c|}{ ArticleInfo } \\
\hline \hline ArticleID & $:$ & 3744 \\
\hline \hline ArticleDOI & $:$ & $10.1186 /$ gb-spotlight-20000817-01 \\
\hline \hline ArticleCitationID & $:$ & spotlight-20000817-01 \\
\hline \hline ArticleSequenceNumber & $:$ & 181 \\
\hline \hline ArticleCategory & $:$ & Research news \\
\hline \hline ArticleFirstPage & $:$ & 1 \\
\hline \hline ArticleLastPage & $:$ & 2 \\
\hline \hline & & RegistrationDate : 2000-08-17 \\
ArticleHistory & $:$ & OnlineDate $\quad$ 2000-08-17 \\
\hline \hline ArticleCopyright & $:$ & BioMed Central Ltd2000 \\
\hline \hline ArticleGrants & $:$ & \\
\hline \hline ArticleContext & $:$ & 130591111 \\
\hline \hline
\end{tabular}




\section{William Wells}

Email: wells@biotext.com

A series of narrow-pH-range overloaded 2D gels, processed using sensitive silver-staining, yields enough spots that the gels could, theoretically, be surveying virtually all of the proteins of budding yeast. But in the August 15 Proceedings of the National Academy of Sciences, Gygi et al. report that proteomics proponents may have been fooling themselves (Proc Natl Acad Sci USA 2000, 97:9390-9395). Gygi et al. select a random region of one such gel and analyze all the visible spots. The genes corresponding to the identified proteins have a codon biascharacteristic of high or medium abundance proteins. Many of these proteins are present in multiple spots, whereas many lower abundance proteins that would be expected to appear in the selected region (based on predicted molecular weight and $\mathrm{pI}$ ) are not detected. This suggests that more sensitive chromatographic processes may be needed for complete proteomics analyses.

\section{References}

1. Proceedings of the National Academy of Sciences, [http://www.pnas.org/]

2. Proteome studies of Saccharomyces cerevisiae: identification and characterization of abundant proteins. 